Our Nature (2010) 8:48-62

\title{
Fertigation Effect of Distillery Effluent on Agronomical Practices of Trigonella foenum-graecum L. (Fenugreek)
}

\author{
V. Kumar* and A.K. Chopra \\ Department of Zoology and Environmental Science, Gurukula Kangri University, Haridwar- 249404 \\ (Uttarakhand), India \\ *E-mail:drvksorwal@yahoo.com
}

Received: 17.10.2010, Accepted: 17.11.2010

\begin{abstract}
The present study was conducted to asses the fertigation effect of distillery effluent as agro-based biofertigant. Different fertigant doses of Distillery effluent (DE) such as 5, 10, 25, 50, 75 and 100\% were used for fertigation of Trigonella foenum-graecum along with control bore well water (BWW). The study revealed that the fertigant, rich in plant nutrients, affected the agronomical characteristics of $T$. foenum-graecum (Pusa early bunching) and physico-chemical characteristics of the soil as well. On irrigation of soil with different effluents up to 90 days of harvesting, there was a significant effect on moisture content $(\mathrm{P}<0.01), \mathrm{EC}, \mathrm{pH}, \mathrm{Cl}$, TOC, $\mathrm{HCO}_{3}^{-}, \mathrm{CO}_{3}^{-2}, \mathrm{Na}^{+}, \mathrm{K}^{+}, \mathrm{Ca}^{2+}, \mathrm{Mg}^{2+}, \mathrm{Fe}^{2+}$, TKN, $\mathrm{NO}_{3}{ }^{2-}, \mathrm{PO}_{4}{ }^{3-}$ and $\mathrm{SO}_{4}{ }^{2-}(\mathrm{P}<0.001)$ and insignificant effect on WHC and bulk density $(\mathrm{P}>0.05)$. There was no significant change in the soil texture. Among various concentrations of DE, irrigation with $100 \%$ DE decreased $\mathrm{pH}(16.66 \%)$ and increased moisture content $(30.82 \%)$, EC $(84.13 \%), \mathrm{Cl}^{-}(292.37 \%)$, TOC $(4311.61 \%), \mathrm{HCO}_{3}{ }^{-}$ (27.76\%), $\mathrm{CO}_{3}^{-2}(32.63 \%), \mathrm{Na}^{+}(273 \%), \mathrm{K}^{+}(31.59 \%), \mathrm{Ca}^{2+}(729.76 \%), \mathrm{Mg}^{2+}(740.47 \%)$, $\mathrm{Fe}^{2+}(301.90 \%), \mathrm{TKN}(1723.32 \%), \mathrm{NO}_{3}^{2-}(98.02 \%), \mathrm{PO}_{4}^{3-}(337.79 \%)$ and $\mathrm{SO}_{4}{ }^{2-}$ (77.78\%). The agronomical parameters such as shoot length, root length, number of roots, root nodule, number of leaves, flowers, pods, pod length, dry weight, chlorophyll content, leaf area index (LAI), crop yield and harvest index (HI) of T. foenum-graecum were recorded to be in increasing order at low concentrations of DE i.e., 5 to $50 \%$ and in decreasing order at high concentrations of DE i.e., 75 to $100 \%$ as compared to control. Stimulation was observed in seed emergence period and shoot length, root length, number of leaves and biomass with the increase in effluent concentration in early seedling growth period.
\end{abstract}

Key words: Distillery effluent, Trigonella foenum-graecum, fertigation, agronomical characteristics

\section{Introduction}

In the past two decades there has been a notable increase in the use of wastewater for crop irrigation, especially in arid and seasonally arid areas of both industrialized and developing countries. It may be due to the increasing scarcity of alternative waters for irrigation, exacerbated by increasing urban demand for potable water supplies, and the growing recognition by water resource planners of the importance and value of wastewater reuse and the high cost of artificial fertilizers and the recognition of the value of nutrients in wastewater, which significantly increase crop yield. In the agriculture, the irrigation water quality is believed to have effects on the soils, crops and the management of water (Shainberg 
and Oster, 1978). Particularly the use of saline water may result in the reduction of crop yield, while the sodic water may deteriorate the physical properties of the soil with consequent reduction in the yield. The disposal of wastewater is a major problem faced by industries, due to generation of high volume of effluent and with limited space for land based treatment and disposal. On the other hand, wastewater is also a resource that can be applied for productive uses since wastewater contains nutrients that have the potential for use in agriculture, aquaculture, and other activities (Hussain et al., 2001). In India there are about 330 distilleries, out of which about 250 units are in operation. The total installed capacity is about 3500 million liters of alcohol (Kaul et al., 1995; AIDA, 2004; Hati et al., 2007). Distilleries generate a huge quantity of wastewater (spent wash) having high COD and BOD load. Effluent from distilleries contains a large amount of dissolved organic matter. This organic matter is readily decomposed by biological action; consequently its discharge in to surface water causes serious damage to aquatic life in stream. The utilization of industrial waste as soil amendment has generated interest in recent times. Most crops give higher potential yields with wastewater irrigation; reduce the need for chemical fertilizers, resulting in net cost savings to farmers. So it is an important aspect to understand the specificity of crop-effluent relationship for their appropriate application in irrigation practices (Kumar et al., 2010). Trigonella foenum-graecum (Fenugreek) is an annual herb of the leguminoseae family. Its seeds are used as spice and its leaves are used as leafy vegetables which are rich in vitamins and minerals. The seeds are protein rich. Fenugreek seeds are used as spice and have medicinal values in the treatment of dyspepsia, rheumatism, asthma and constipation. It is also an important source of diosgenin. It is also a good source of cattle fodder. Keeping in view the reuse of wastewater effluent and the economic importance of $T$. foenum-graecum, the present investigation was undertaken to use the distillery effluents as a source of biofertilizer for more productivity of this crop.

\section{Materials and methods Experimental design}

A field study was conducted in the experimental garden of the Department of Zoology and Environmental Sciences, Faculty of Life Sciences, Gurukula Kangri University Haridwar( $29^{\circ} 55^{\prime} 10.81^{\prime \prime} \mathrm{N}$ and $\left.78^{\circ} 07^{\prime} 08.12^{\prime \prime} \mathrm{E}\right) \quad$ during the period November, 2008-February, 2009 to study the effect of distillery effluent on Trigonella foenum-graecum. Poly bags (dia. $30 \mathrm{~cm}$ ) were used for growing the $T$. foenumgraecum plant. The experiment was conducted under completely randomized designed and replicated by four times. The number of poly bags (28) having soil were used for the cultivation of $T$. foenumgraecum. Proper distance was maintained between each replicate $(30 \mathrm{~cm})$, between each treatment $(60 \mathrm{~cm})$ and plant to plant $(5$ $\mathrm{cm}$ ) for the maximum performance of the crop. Each poly bag was made porous for aeration and it was labeled for the various treatments viz., 0 (BWW), 5, 10, 25, 50, 75 and $100 \%$.

\section{Effluent collection and analysis}

Shamli Distillery and Chemical Works, Shamli, Muzaffarnagar (Uttar Pradesh) manufactures wine as its main product from molasses at the rate of $150 \mathrm{Kg} \mathrm{L}$ per day (KLD) was selected for the collection of its 
effluent sample. The samples of DE were collected in the plastic containers from a settling tank installed by the distillery used to reduce the BOD and solids of the factory and were brought to the laboratory. These samples were analyzed for various physicochemical parameters (color, odor, TS, DS, $\mathrm{SS}$, turbidity, $\mathrm{EC}, \mathrm{pH}, \mathrm{DO}, \mathrm{BOD}, \mathrm{COD}, \mathrm{Cl}^{-}$ , alkalinity, $\mathrm{HCO}_{3}{ }^{-}, \mathrm{CO}_{3}^{-2}, \mathrm{Na}^{+}, \mathrm{K}^{+}, \mathrm{Ca}^{2+}$, $\mathrm{Mg}^{2+}, \mathrm{Fe}^{2+}, \mathrm{TKN}, \mathrm{NO}_{3}{ }^{2-}, \mathrm{PO}_{4}^{3-}$ and $\mathrm{SO}_{4}{ }^{2-}$ ) and microbiological parameters, standard plate count (SPC) and most probable number (MPN) following standard methods (APHA, 2005) and were used as fertigant in different concentrations viz., 5, 10, 25, 50, 75 and $100 \%$ for cultivation of $T$. foenumgraecum.

\section{Soil preparation, filling of poly bags, sampling and analysis}

The soil used was collected from a depth of $0-15 \mathrm{~cm}$. Each poly bag $(30 \times 30 \mathrm{~cm})$ was filled with this $5 \mathrm{~kg}$ well prepared soil, earlier air-dried and sieved to remove debris and mixed with equal quantity of farmyard manure. Five $\mathrm{Kg}$ of soil in each of the twenty eight of poly bags were fertigated twice in a week with $500 \mathrm{ml}$ of DE in six concentrations 5, 10, 25, 50, 75 and 100\% along with BWW. The soil was analyzed before sowing and after harvesting the crop for the physico-chemical parameters following standard methods (Buurman et al., 1996 for soil temperature, moisture content and EC), (Bouyoucos, 1962 for soil texture), (Carter, 1993 for bulk density, and WHC). The soil $\mathrm{pH}$ was determined at soil: water ratio of 1:1 using glass electrode $\mathrm{pH}$ meter; and $\mathrm{Cl}^{-}, \mathrm{TOC}, \mathrm{HCO}_{3}^{-}, \mathrm{CO}_{3}^{-2}, \mathrm{Na}^{+}$, $\mathrm{K}^{+}, \mathrm{Ca}^{2+}, \mathrm{Mg}^{2+}, \mathrm{Fe}^{2+}, \mathrm{TKN}, \mathrm{NO}_{3}{ }^{2-}, \mathrm{PO}_{4}{ }^{3-}$ and $\mathrm{SO}_{4}{ }^{2-}$ were determined as per standard methods (APHA, 2005).

\section{Sowing of seeds, irrigation pattern and collection of crop parameters data}

In each case, the DE with volume of $500 \mathrm{ml}$ was applied with its dilutions of $0,5,10,25$, 50,75 and $100 \%$ concentration per $5 \mathrm{~kg}$ soil and then left for 2 weeks to allow for mineralization and further irrigation of the crop plant. The seeds of $T$. foenum-graecum (var. pusa early bunching) were procured from ICAR, Pusa, New Delhi and sterilized with 0.01 mercuric chloride and was soaked for $12 \mathrm{hrs}$. Fifteen seeds were initially sown in each poly bag at equal distance between plant to plant $(5 \mathrm{~cm})$ in the last week of November, 2008. Ten plants out of the germinated were maintained in each poly bag and each set was replicated four times. Thus, forty plants were grown for each treatment as well for the control group. Each group of crop plant received the DE as fertigant doses twice in a week with concentrations of $5,10,25,50,75$ and $100 \%$ of effluent separately along with control (BWW) and no drainage was allowed. The various agronomical parameters of $T$. foenum-graecum from germination to maturity (0-90 days) were determined following standard methods (Chandrasekhar et al., 1998 for seed emergence, seed germination, shoot length, root length, number of leaves, biomass, number of flowers, number of secondary roots, root nodules, number of pods, pod length and crop yield), (Milner and Hughes, 1968 for biomass) and (Porra, 2002 for chlorophyll content), (Chapagain, 1991 for relative toxicity), (Denison and Russotti, 1997 for LAI) and (Sinclair, 1998 for harvest index) is following the methods:

Relative toxicity (RT) $=\frac{\text { Germination \% with control }}{\text { Germination \% with effluent }} \times 100$ 


$$
\begin{aligned}
& \text { Leaf area index }(\mathrm{LAI})=\frac{\text { Leaf area }}{\text { Land area }} \\
& \text { Harvest index }(\mathrm{H})=\frac{\text { Grain weight }(\mathrm{g} .)}{\text { Total plant weight }(\mathrm{g} .)} \times 100
\end{aligned}
$$

\section{Statistical analysis}

Data were analyzed for one way analysis of variance (ANOVA) for determining the difference between soil parameters before and after effluent irrigation, crop parameters and effluent concentration, standard deviation, coefficient of correlation for soil, crop parameter and effluent concentrations were also calculated with the help of MS Excel, SPSS 12.0 and Sigma plot, 2000.

\section{Results and discussion \\ Effluent characteristics}

The mean \pm SD values of physico-chemical and microbiological parameters color, odor, turbidity, EC, TS, DS, SS, alkalinity, $\mathrm{HCO}_{3}^{-}$ , $\mathrm{CO}_{3}^{-2}, \mathrm{DO}, \mathrm{BOD}, \mathrm{COD}, \mathrm{Cl}^{-}, \mathrm{Na}^{+}, \mathrm{K}^{+}$, $\mathrm{Ca}^{2+}, \mathrm{Mg}^{2+}, \mathrm{Fe}^{2+}, \mathrm{TKN}, \mathrm{NO}_{3}{ }^{2-}, \mathrm{PO}_{4}{ }^{3-}, \mathrm{SO}_{4}{ }^{2-}$, SPC, MPN of DE (Spent wash) are given in table 1.

The results revealed that the DE was acidic in nature $\mathrm{pH}$ (5.28). Among various parameters, BOD $\left(1631.50 \mathrm{mg} \mathrm{L}^{-1}\right), \mathrm{COD}$ $\left(2458.50 \mathrm{mg} \mathrm{L}^{-1}\right), \mathrm{Cl}^{-}\left(848.00 \mathrm{mg} \mathrm{L}^{-1}\right)$, $\mathrm{HCO}_{3}^{-}\left(959.50 \mathrm{mg} \mathrm{L}^{-1}\right), \mathrm{Ca}^{2+}(454.50 \mathrm{mg} \mathrm{L}$ $\left.{ }^{1}\right)$, TKN (427.50 mg L $\left.{ }^{-1}\right), \mathrm{NO}_{3}{ }^{2-}(372.00 \mathrm{mg}$ $\left.\mathrm{L}^{-1}\right), \mathrm{MPN}\left(32.46 \times 10^{4} \mathrm{MPN} 100 \mathrm{ml}^{-1}\right)$, were not found to be in the prescribed limit of Indian Irrigation Standards (BIS, 1991). The higher values of TS $\left(4285 \mathrm{mg} \mathrm{L}^{-1}\right)$, BOD (544.5 $\left.\mathrm{mg} \mathrm{L}^{-1}\right)$ and COD (2433 $\mathrm{mg} \mathrm{L}^{-}$ $\left.{ }^{1}\right)$ indicated the higher inorganic and organic load in distillery effluent of Lords distillery, Nand Ganj, Ghazipur (U.P.), India as also indicated by Pandey et al. (2007).

\section{Soil characteristics}

The mean \pm SD of various physico-chemical parameters of the soil before and after fertigation with different concentrations of DE viz., 5, 10, 25, 50, 75 and 100\% along with control (BWW) for 90 days are given in table 2.

Kaushik et al. (2005) reported the impact of distillery effluent irrigation on various soil properties. The effluent irrigation increase the $\mathrm{EC}, \mathrm{pH}$, total organic carbon (TOC), total Kjeldahl nitrogen (TKN), available phosphorus, exchangeable $\mathrm{K}, \mathrm{Na}, \mathrm{Ca}, \mathrm{Cl}$, microbial population and soil enzyme activities. Kannan and Upreti (2008) reported that distillery effluent (spent wash) discharged as waste water contains various nutrients and toxic chemicals that can contaminate water and soil and may affect the common crops if used for agricultural irrigation. Kumar et al. (2010) reported that on irrigation of the soil with paper mill effluent, decreased the moisture content, WHC, bulk density and $\mathrm{pH}$ and significantly increased the parameters like $\mathrm{EC}, \mathrm{Cl}^{-}, \mathrm{K}^{+}$and $\mathrm{Ca}^{2+}, \mathrm{Na}^{+}, \mathrm{NO}_{3}{ }^{2-}, \mathrm{PO}_{4}{ }^{3-}$ and $\mathrm{SO}_{4}^{2-}$ in the soil.

The $\mathrm{pH}$ is an important parameter as many nutrients are available only at a particular range of $\mathrm{pH}$ for plant uptake. A $\mathrm{pH}$ value at 6.0-8.2 $\mathrm{pH}$ provides predominating bacterial activity and is favorable for maximum yield of crops. A shift in $\mathrm{pH}$ outside that range renders the nutrients less available, even though they remain in the soil. Under acidic conditions, elements such as iron, aluminium, manganese and the heavy metals (zinc, copper, and chromium) become highly soluble and may create problems for vegetation (Charman and Murphy, 1991). The higher concentration of $\mathrm{Na}$ in soil after effluent irrigation is associated with 
V. Kumar and A.K. Chopra / Our Nature (2010) 8: 48-62

Table 1. Physico-chemical and microbiological characteristics of control (Bore well water) and distillery effluent of the Shamli distillery and Chemical works, Shamli, Muzaffarnagar (Uttar Pradesh)

\begin{tabular}{|c|c|c|c|c|}
\hline Parameters & $\begin{array}{l}\text { Control } \\
(\text { BWW) }\end{array}$ & Effluent & $\begin{array}{l}\text { BIS for drinking } \\
\text { water }\end{array}$ & $\begin{array}{l}\text { BIS for } \\
\text { irrigation water }\end{array}$ \\
\hline Color (Hazen units, Max) & colorless & light reddish & 5 & 25 \\
\hline Odor (TON) & none & molasses odor & agreeable & - \\
\hline Turbidity (NTU) & $4.46 \pm 0.31$ & $30.57 \pm 3.30$ & 4 & 10 \\
\hline $\mathrm{EC}\left(\mathrm{dS} \mathrm{m} \mathrm{m}^{-1}\right)$ & $1.10 \pm 0.08$ & $11.75 \pm 1.71$ & - & - \\
\hline $\mathrm{TS}\left(\mathrm{mg} \mathrm{L}^{-1}\right)$ & $324 \pm 4.00$ & $1836.50 \pm 13.10$ & 600 & 2100 \\
\hline $\mathrm{DS}\left(\mathrm{mg} \mathrm{L}^{-1}\right)$ & $302.66 \pm 1.15$ & $1486.50 \pm 10.25$ & 500 & 1900 \\
\hline $\mathrm{SS}\left(\mathrm{mg} \mathrm{L}^{-1}\right)$ & $21.33 \pm 3.05$ & $356.00 \pm 11.20$ & 100 & 200 \\
\hline $\mathrm{pH}$ & $7.60 \pm 0.20$ & $5.28 \pm 0.50$ & $6.5-8.5$ & $5.5-9.0$ \\
\hline $\mathrm{DO}\left(\mathrm{mg} \mathrm{L}^{-1}\right)$ & $6.87 \pm 0.11$ & nil & $6-8$ & - \\
\hline $\mathrm{BOD}_{5}\left(\right.$ at $\left.20^{\circ} \mathrm{C}\right)\left(\mathrm{mg} \mathrm{L}^{-1}\right)$ & $4.86 \pm 0.30$ & $1631.50 \pm 8.54$ & 4.0 & 100 \\
\hline $\mathrm{COD}\left(\mathrm{mg} \mathrm{L}^{-1}\right)$ & $18.68 \pm 0.27$ & $2458.50 \pm 8.23$ & $150-200$ & 250 \\
\hline $\mathrm{Cl}^{-}\left(\mathrm{mg} \mathrm{L}^{-1}\right)$ & $245.80 \pm 2.90$ & $848.00 \pm 14.61$ & 250 & 500 \\
\hline Alkalinity $\left(\mathrm{mg} \mathrm{L}^{-1}\right)$ & $168.42 \pm 0.43$ & $435.14 \pm 7.08$ & 200 & 600 \\
\hline $\mathrm{HCO}_{3}^{-}\left(\mathrm{mg} \mathrm{L}^{-1}\right)$ & $282.00 \pm 13.95$ & $959.50 \pm 13.30$ & 250 & 450 \\
\hline $\mathrm{CO}_{3}^{-2}\left(\mathrm{mg} \mathrm{L}^{-1}\right)$ & $105.75 \pm 5.91$ & $269.38 \pm 8.94$ & 150 & 300 \\
\hline $\mathrm{Na}^{+}\left(\mathrm{mg} \mathrm{L}^{-1}\right)$ & $9.65 \pm 1.25$ & $143.00 \pm 10.00$ & - & - \\
\hline $\mathrm{K}^{+}\left(\mathrm{mg} \mathrm{L}^{-1}\right)$ & $5.54 \pm 2.25$ & $247.75 \pm 14.24$ & - & - \\
\hline $\mathrm{Ca}^{2+}\left(\mathrm{mg} \mathrm{L}^{-1}\right)$ & $23.46 \pm 4.16$ & $454.50 \pm 7.19$ & 75 & 200 \\
\hline $\mathrm{Mg}^{2+}\left(\mathrm{mg} \mathrm{L}^{-1}\right)$ & $12.15 \pm 1.50$ & $145.00 \pm 9.02$ & - & - \\
\hline $\mathrm{Fe}^{2+}\left(\mathrm{mg} \mathrm{L}^{-1}\right)$ & $0.28 \pm 0.04$ & $15.25 \pm 2.99$ & 0.3 & 50 \\
\hline TKN (mg L $\left.{ }^{-1}\right)$ & $24.27 \pm 5.08$ & $427.50 \pm 8.23$ & - & 100 \\
\hline $\mathrm{NO}_{3}^{2-}\left(\mathrm{mg} \mathrm{L}^{-1}\right)$ & $16.16 \pm 0.35$ & $372.00 \pm 9.93$ & 45 & 100 \\
\hline $\mathrm{PO}_{4}{ }^{3-}\left(\mathrm{mg} \mathrm{L}^{-1}\right)$ & $0.11 \pm 0.02$ & $162.50 \pm 4.12$ & - & - \\
\hline $\mathrm{SO}_{4}^{2-}\left(\mathrm{mg} \mathrm{L}^{-1}\right)$ & $198.63 \pm 0.25$ & $621.75 \pm 5.91$ & 200 & 1000 \\
\hline $\mathrm{SPC}\left(\mathrm{SPC} \mathrm{ml} \mathrm{m}^{-1}\right)$ & $63 \pm 6.20$ & $14.64 \times 10^{6} \pm 1223.11$ & - & - \\
\hline MPN (MPN100 $\mathrm{ml}^{-1}$ ) & - & $32.46 \times 10^{4} \pm 1208.58$ & 50 & 5000 \\
\hline
\end{tabular}

Mean \pm of three values, BWW $=$ Bore well water, BIS $=$ Bureau of Indian standard

presence of higher concentration of carbonate, bicarbonate in the effluent (Thompson et al., 2001). Nitrate is the most essential and available form of nitrogen to plants because plant roots take up nitrogen in the form of $\mathrm{NO}_{3}^{2-}$ and $\mathrm{NH}_{4}^{+}$. Plants respond quickly to application of nitrogen and it encourages the vegetative growth and gives a deep green colour to the leaves. The overall increase in nitrogen is due to the use of wastewater, which contains higher amount of nitrogen. Long term application of distillery effluent proved useful in significantly increasing TOC, TKN, K, P and soil enzymatic activities in the soil but tended to build up harmful concentration of $\mathrm{Na}$ that could be chelated by bioamendments. Short terms studies, application of 50\% distillery effluent along with bioamendments proved to be the most useful in improving the properties of sodic soil (Kaushik et al., 2005). Effluent irrigation generally adds significant quantities of salts to the soil environment, such as sulfates, phosphates, bicarbonates, chlorides of the cations sodium, calcium, potassium and magnesium they stimulate the growth at lower concentration but inhibit at higher concentration (Patterson et al., 2008). 
During present study, the soil characteristics have been found to change on irrigation with DE. It was observed that after 90 days of $T$. foenum-graecum cropharvesting, the soil particle size depicted that the soil was loamy sand and no drastic change in soil texture occurred with the application of all the concentrations of DE throughout the period of the trial. Moisture content was significant and positively $(r=$ $+0.97, \mathrm{P}<0.01)$ correlated while $\mathrm{BD}(\mathrm{r}=$ $+0.96)$ and WHC $(\mathrm{r}=+0.96)$ were insignificantly $(\mathrm{P}>0.05)$ but positively correlated with the increase in DE concentrations. As the concentrations of DE increased from 5 to $100 \%$ for irrigation, moisture content, BD and WHC also increased. It was quite interesting to note that among various concentrations, the concentrations such as 25, 50, 75 and $100 \%$ significantly $(\mathrm{P}<0.01)$ affected the moisture content. The irrigation with 100\% concentration of DE significantly increased the moisture content, $\mathrm{WHC}$ and bulk density, $\mathrm{EC}, \mathrm{Cl}^{-}, \mathrm{TOC}, \mathrm{HCO}_{3}^{-}, \mathrm{CO}_{3}^{-2}, \mathrm{Na}^{+}$, $\mathrm{K}^{+}, \mathrm{Ca}^{2+}, \mathrm{Mg}^{2+}, \mathrm{Fe}^{2+}, \mathrm{TKN}, \mathrm{NO}_{3}^{2-}, \mathrm{PO}_{4}^{3-}$ and $\mathrm{SO}_{4}{ }^{2-}$ of the soil while the $\mathrm{pH}$ was found to decrease.

The statistical analysis on data has shown that the soil $\mathrm{pH}$ was significantly affected by DE concentrations. It was recorded to be significantly and negatively correlated $(\mathrm{r}=-0.97)$ with $\mathrm{DE}$ concentrations and slightly acidic in nature at $100 \%$ effluent. However, EC $(\mathrm{r}=+0.98)$, $\mathrm{Cl}^{-}(\mathrm{r}=+0.98)$, TOC $(\mathrm{r}=+0.99), \mathrm{HCO}_{3}^{-}(\mathrm{r}$ $=+0.98), \mathrm{CO}_{3}^{-2}(\mathrm{r}=+0.96), \mathrm{Na}^{+}(\mathrm{r}=+0.97)$, $\mathrm{K}^{+}(\mathrm{r}=+0.64), \mathrm{Ca}^{2+}(\mathrm{r}=+0.75), \mathrm{Mg}^{2+}(\mathrm{r}=$ $+0.62), \mathrm{Fe}^{2+}(+0.99)$, TKN $(\mathrm{r}=+0.99)$, $\mathrm{NO}_{3}{ }^{2-}(\mathrm{r}=+0.96), \mathrm{PO}_{4}{ }^{3-}(\mathrm{r}=+0.98)$ and $\mathrm{SO}_{4}^{2-}(\mathrm{r}=+0.96)$ were significantly $(\mathrm{P}<0.05)$ and positively correlated with all the DE concentrations.
The ANOVA analysis on the data showed that different concentrations of DE affected differently on various nutrients. The DE concentrations viz., 50, 75 and $100 \%$ showed significant $(\mathrm{P}<0.001)$ effect on $\mathrm{pH}$. The concentrations of DE, 25, 50, 75 and $100 \%$ of distillery effluents had a significant $(\mathrm{P}<0.001)$ effect on $\mathrm{EC}, \mathrm{Cl}^{-}$, TOC, $\mathrm{HCO}_{3}^{-}, \mathrm{CO}_{3}^{-2}, \mathrm{Na}^{+}, \mathrm{K}^{+}, \mathrm{Ca}^{2+}, \mathrm{Mg}^{2+}$, $\mathrm{Fe}^{2+}, \mathrm{TKN}, \mathrm{PO}_{4}{ }^{3-}$ and $\mathrm{SO}_{4}{ }^{2-}$ as compared to control. Among these parameters, EC, $\mathrm{HCO}_{3}^{-}, \mathrm{TKN}, \mathrm{NO}_{3}{ }^{2-}, \mathrm{Cl}^{-}, \mathrm{TOC}, \mathrm{K}^{+}$and $\mathrm{Ca}^{2+}$ were also found to be significantly $(\mathrm{P}<0.001)$ affected with $10 \%$ while $\mathrm{EC}$, $\mathrm{HCO}_{3}^{-}, \mathrm{TKN}$, and $\mathrm{NO}_{3}{ }^{2-}$ were also recorded to be significantly $(\mathrm{P}<0.001)$ affected with $5 \%$ effluent treatments.

\section{Agronomical characteristics \\ Germination and seedling growth stage}

The seed emergence period, seed germination and relative toxicity (RT) against seed germination of $T$. foenumgraecum at different concentrations viz., 5, $10,25,50,75$ and $100 \%$ along with control (BWW) are shown in table 3.

It has been observed that the availability, uptake and leaching of nutrients is greatly influenced by a number of physico-chemical factors. Among various physico-chemical factors, the $\mathrm{pH}$ plays a significant role in the soil. In the acidic soil environment the availability of the basic cations like $\mathrm{Ca}^{2+}, \mathrm{Mg}^{2+}, \mathrm{K}^{+}$and $\mathrm{Na}^{+}$ becomes lower due to leaching. Thus the availability of these nutrients decreases as per increase the acidic character of the soil, however it directly effect the vegetative growth of the crop plants it gradually decreased as per increase the effluent concentration (Charman and Murphy, 1991; Patterson et al., 2008 and Kumar et al., 2010). Salts are usually most damaging to 
young plants but not necessarily at the time of germination, although high salt concentration can slow seed germination by several days or completely inhibit it. Because soluble salts move readily with water, evaporation moves salts to the soil surface where they accumulate and make the soil surface harden as a result delay in germination (Kaushik et al., 2005 and Kumar et al., 2010). The major effect of acidic $\mathrm{pH}$ is to increase the solubility of all micronutrients (except chlorine, boron and molybdenum), especially those of iron, zinc, copper and manganese. Also phosphate is often not readily available to some plants because of its precipitation in the soil solution. Although toxicity due to high concentration of sodium, chlorides or other ions can occur, salts usually affect plant growth because of the osmotic effect. High salt concentration increases the potential forces that hold water in the soil and makes it more difficult for uptake to plant roots. Many foreign substances in the soil environment such as diverse acids, alkali, salts of metals, phenolics, fluorides, and so on from polluted water influenced germination. Because soluble salts move readily with water, evaporation moves salts to the soil surface where they accumulate and make the soil surface harden as a result delay in germination (Thompson et al., 2001 and Kumar et al., 2010).

In present study ANOVA analysis on data showed that DE concentrations insignificantly $(\mathrm{P}>0.05)$ affected emergence period as compared to control. The seed emergence period of $T$. foenum-graecum was negatively correlated $(\mathrm{r}=-0.91)$ i.e., it decreased with increase in the effluent concentrations. Among different concentrations, seed emergence was much better on irrigation of the crop with $100 \%$ effluent treatment. It may be due to that in the emergence period the mineralization and nutrients accumulation due to effluent irrigation, it catalyzes the physiological activities, thus it stimulate the seed emergence and germination as per increase the effluent concentration. The germination behaviour of $T$. foenum-graecum was also affected insignificantly $(\mathrm{P}>0.05)$ at different concentrations of DE. As the concentrations of DE increased, the germination percent decreased. The maximum seed germination of $T$. foenum-graecum was recorded at control. The maximum RT of DE against the seed germination of $T$. foenum-graecum was noted with $100 \%$ effluent concentration. It was found to be significant $(\mathrm{r}=+0.94, \quad \mathrm{P}<0.05)$ and positively correlated with different effluent concentrations. This type of germination pattern is likely due to the presence of toxicants in the higher concentration of distillery effluent which may inhibit the germination at higher concentrations as observed earlier for the crop T. foenumgraecum (Kumar et al., 2010), for Triticum aestivum, Pisum sativm and Abelmoschus esculentus (Sandeep et al., 2007) and for tomato, chilli, bottle gourd, cucumber and onion (Ramana et al., 2002). However, the germination speed, peak value and germination value of Triticum aestivum, Pisum sativm and Abelmoschus esculentus, has been reported to increase with a dilution of effluent from 25 to $50 \%$ concentration and decrease with 50 to $100 \%$ distillery effluent concentration (Sandeep et al., 2007). Kannan and Upreti (2008) reported that the percentage of germination, speed of germination index, vigor index and length of root in mung bean (Vigna radiata L.R. Wilczek) were significantly concentrationdependent and were declined in untreated 
effluent irrigation. Kaushik et al. (2005) reported that application of $50 \%$ distillery effluent favoured successful germination and improved seedling growth of pearl millet.

Seedling stage parameters such as shoot length, root length, number of leaves and dry weight of $T$. foenum-graecum at 21 and 30 days are shown in table 4.

It is evident from the table and ANOVA analysis on the data that in seedling stage, the effluent concentrations affected the shoot length, root length number of leaves and dry weight of $T$. foenum-graecum at 21 days significantly $(\mathrm{P}<0.05)$ at 50,75 and $100 \%$ of $\mathrm{DE}$ concentrations after 21 days of irrigation while and dry weight were also affected significantly at $25 \%$ respectively. Root length of $T$. foenum-graecum was also found to be significantly different at $5 \%$ and $10 \%$ respectively. Dry weigh/ plant of the crop was also affected significantly $(\mathrm{P}<0.001) \quad$ with different effluent concentrations of DE. Shoot length, root length and dry weight of $T$. foenumgraecum were also found to be significantly $(\mathrm{P}<0.01)$ affected with DE. The DE concentrations 50, 75 and $100 \%$ showed significant $(\mathrm{P}<0.05)$ effect on shoot length, root length number of leaves and dry weight of $T$. foenum-graecum at 30 days.

In the seedling stage (21-30 days) the crop performance was observed to increase with increase in effluent concentrations. It may be likely due to competitive uptake of nutrients from the soil that may result in stimulation of the plant performance in the seedling stage.

\section{Vegetative growth stage}

The parameters of vegetative growth stage (at 45 days) such as shoot length, root length, number of leaves, dry weight, chlorophyll content and leaf area index (LAI) of $T$. foenum-graecum at different concentrations of DE viz., 5, 10, 25, 50, 75 and $100 \%$ along with control (BWW) are given in tables 3 and 4 .

It has been observed that tannery effluent stimulates the synthesis of chlorophyll which was accelerated at low concentration of the effluent but certain toxicants inhibited the growth of Vigna (Vigna unguiculata), tomato (Lycopersicon esculentum), cotton (Gossypium hirsutum) and black gram (Vigna mungo) crop plants (Karunyal et al., 1994). In present study, the ANOVA indicated that the difference in shoot length of $T$. foenum-graecum was affected significantly $(\mathrm{P}<0.05)$ with 75 and $100 \%$ concentrations of DE while root length of $T$. foenum-graecum was found significantly $(\mathrm{P}<0.05)$ different with 25 and $50 \%$ concentrations of DE. Number of leaves of $T$. foenum-graecum were noted significantly $(\mathrm{P}<0.05)$ different at 50 and $75 \%$ of DE. However, the dry weight/plant of the crop was affected significantly $(\mathrm{P}<0.001)$ at 25, 50, 75 and $100 \%$ effluent. The DE concentrations of 10, 25 and $50 \%$, significantly $(\mathrm{P}<0.01)$ affected the chlorophyll content while DE concentrations 25 to $100 \%$ affected the LAI significantly $(\mathrm{P}<0.05)$ of $T$. foenumgraecum (Tab. 3). It is very important stage (vegetative stage) in the life span of crop plant as availability and uptake of nutrients directly affect the biomass, flowering and grain filling. The crop performance decreased with the increase in the effluent concentrations. It may be likely due to that the acidic nature of distillery effluent made the calcium, $\mathrm{Ca}^{2+}$, magnesium, $\mathrm{Mg}^{2+}$, potassium, $\mathrm{K}^{+}$and sodium $\mathrm{Na}^{+}$cations less available due to leaching to the crop plants 
V. Kumar and A.K. Chopra / Our Nature (2010) 8: 48-62

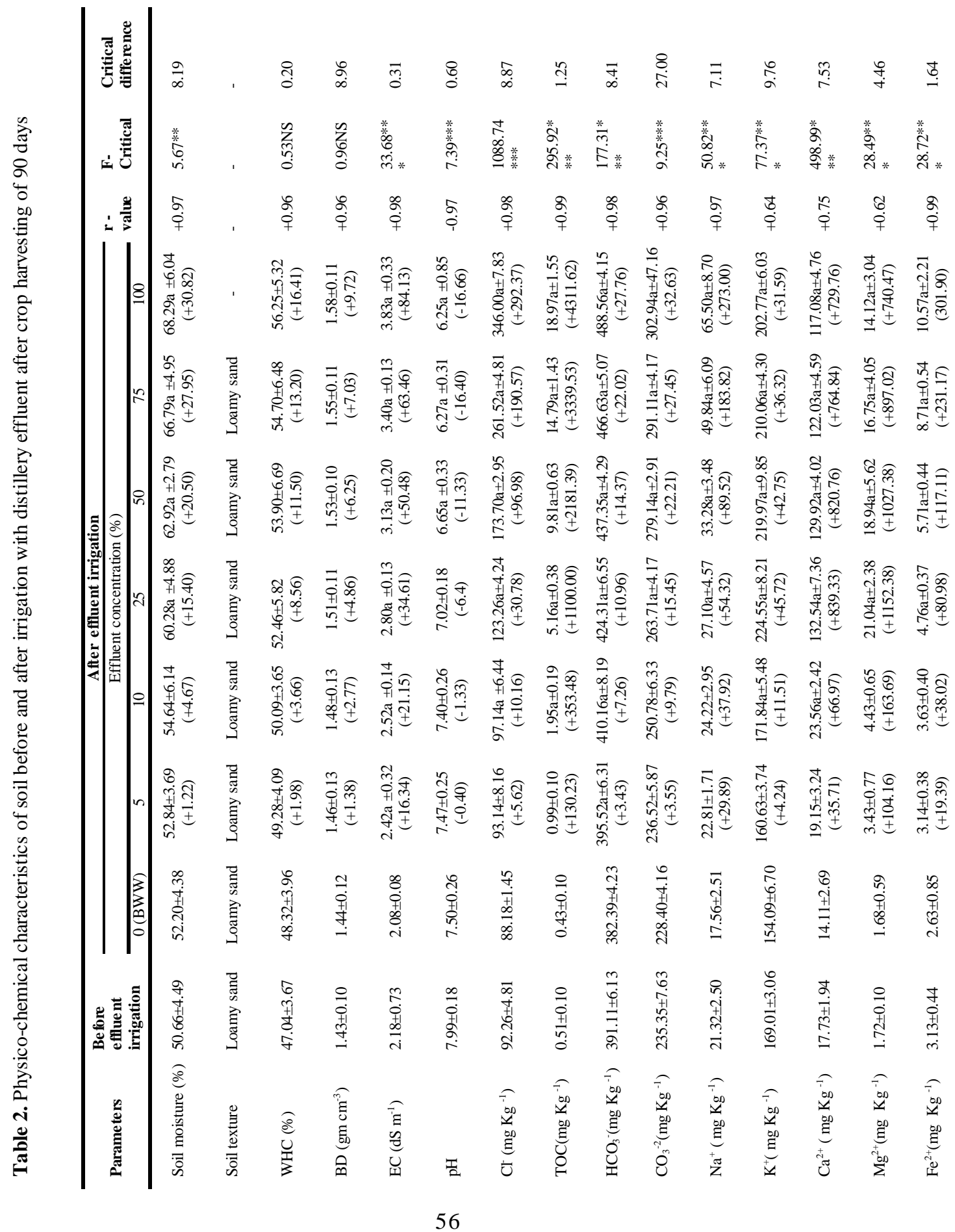


V. Kumar and A.K. Chopra / Our Nature (2010) 8: 48-62

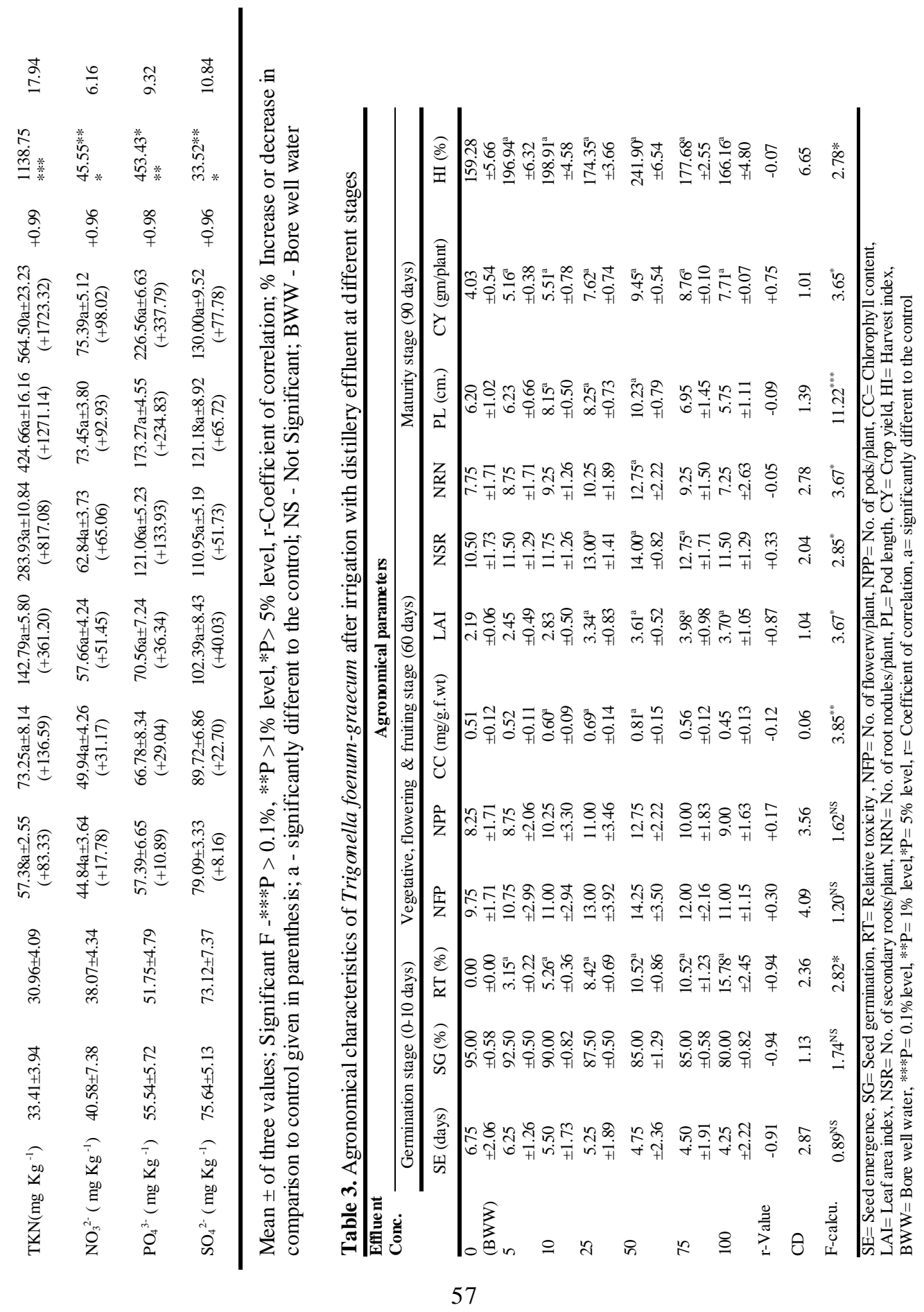




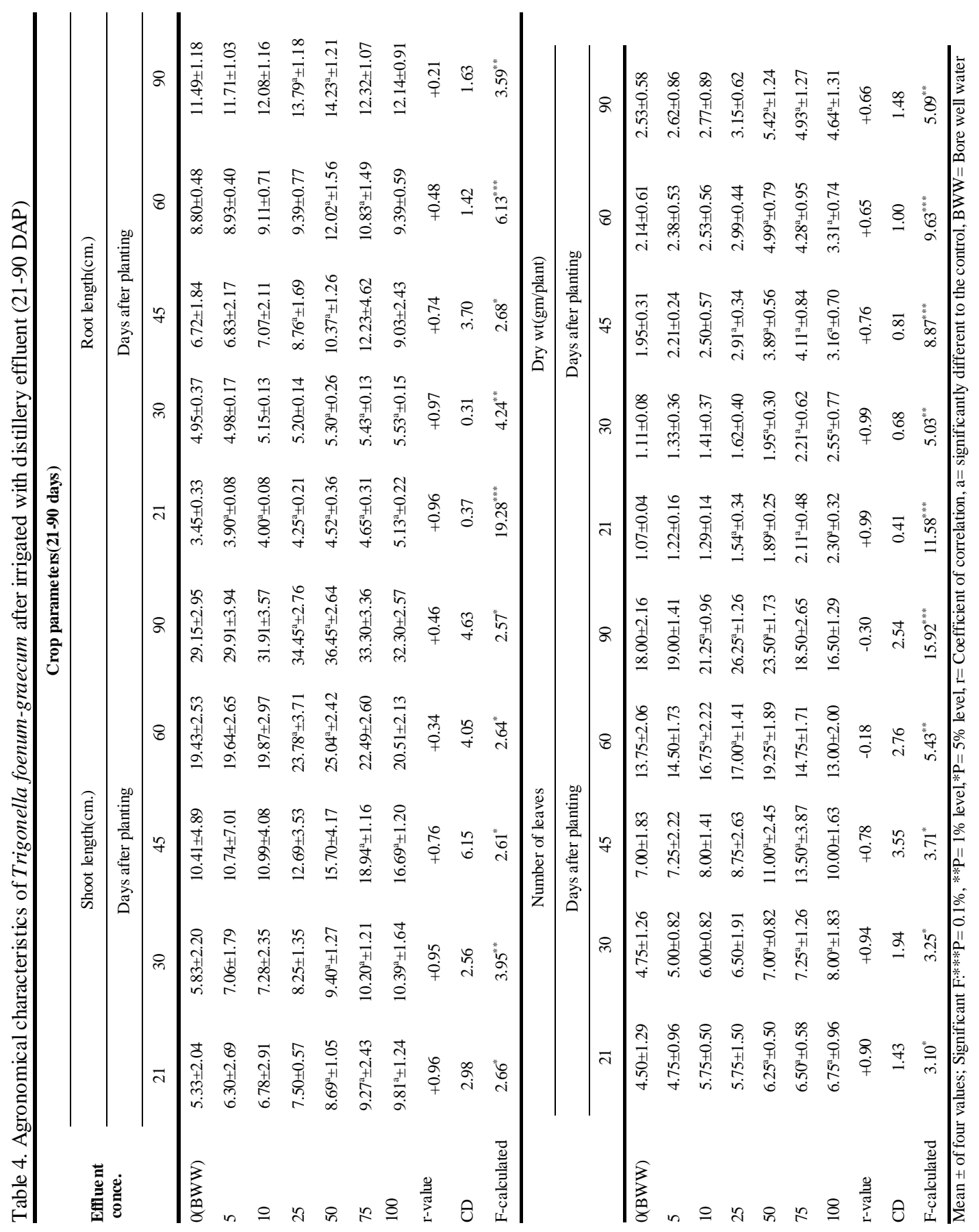


by gradually neutralizing the basic environment of the soil and turned it into more acidic.

\section{Flowering and fruiting stage}

The various parameters of flowering and fruiting stage (at 60 days) such as shoot length, root length, number of leaves, dry weight, number of flowers and number of pods/plant of $T$. foenum-graecum at different concentrations of DE viz., 5, 10, 25, 50, 75 and $100 \%$ along with control (BWW) are given in tables 3 and 4 .

In present study, the ANOVA indicated that the difference in shoot length of $T$. foenum-graecum was recorded significantly $(\mathrm{P}<0.05)$ different at 25 and $50 \%$ concentrations of DE while root length was found significantly $(\mathrm{P}<0.001)$ different at 25 and $50 \%$ concentrations of DE. Number of leaves of $T$. foenum-graecum was noted significantly $(\mathrm{P}<0.01)$ different at 10,25 and $50 \%$ while dry weight was affected significantly $(\mathrm{P}<0.001)$ at 50,75 and $100 \%$ concentrations of DE. The number of flowers and number of pods of $T$. foenum-graecum were affected insignificantly $(\mathrm{P}>0.05)$ with different effluent concentrations of DE.

\section{Maturity stage}

The various parameters of maturity stage (at 90 days) such as shoot length, root length, number of leaves, dry weight, number of secondary roots, root nodules, pod length crop yield/plant and $\mathrm{HI}$ of $T$. foenumgraecum at different concentrations of $\mathrm{DE}$ viz., 5, 10, 25, 50, 75 and $100 \%$ along with control (BWW) are given in tables 3 and 4.

Orhue et al. (2005) recorded maximum chlorophyll content in Zea mays at $25 \%$ brewery effluent concentration while plant height, biomass and leaf number were maximum at $100 \%$ concentration. Osaigbovo et al. (2006) reported maximum plant height and number of leaves and chlorophyll content at $25 \%$ of pharmaceutical effluent treatment on maize plant. Saravanamoorthy and Ranjitha Kumari (2007) recorded that increased concentration of textile effluent in irrigation decreased the seed germination percentage of two varities of Arachis hypogaea as TMV-10 and JL-24 showing the maximum germination percentage at $50 \%$ effluent concentration of the effluent. Maximum shoot and root length were found at $75 \%$ in both of these varieties. Total chlorophyll content has been found to decrease gradually with the increasing effluent concentration. The maximum chlorophyll content was recorded at 50\% in JL-24 while at $75 \%$ in case of TMV-10. The number of pods was also recorded higher at 50\% effluent concentration in both species. Bharagava et al. (2008) reported that in soil irrigated with post methanated distillery effluent increase in the chlorophyll and protein contents in Indian mustard plants (Brassica nigra L.) at the lower concentrations (25 and 50\%) of post methanated distillery effluent at initial exposure periods followed by a decrease at higher concentrations (75 and 100\%) of distillery effluent as compared to their respective controls.

In present study, the ANOVA indicated that the difference in shoot length of $T$. foenum-graecum was recorded significantly $(\mathrm{P}<0.05)$ different at 25 and $50 \%$ concentrations of DE while root length was found significantly $(\mathrm{P}<0.01)$ at 25 and $50 \%$ concentrations of DE. Number of leaves of $T$. foenum-graecum was noted significantly $(\mathrm{P}<0.001)$ different at 10,25 and $50 \%$ while dry weight was affected 
significantly $(\mathrm{P}<0.01)$ at 50,75 and $100 \%$ concentrations of DE. Number of secondary roots/plant of $T$. foenum-graecum was recorded significantly $(\mathrm{P}<0.05)$ different with 25,50 and $75 \%$ while number of root nodules was found significantly $(\mathrm{P}<0.05)$ different at $25 \%$ concentration of $\mathrm{DE}$. The concentrations of $\mathrm{DE} 10,25$ and $50 \%$ showed significant $(\mathrm{P}<0.001)$ effect on pod length of $T$. foenum-graecum. The crop yield and $\mathrm{HI}$ of $T$. foenum-graecum were affected significantly $(\mathrm{P}<0.05)$ with 5 to $100 \%$ concentrations of DE. It is likely to occur due to the more and more accumulation of salts with the increase in concentrations of the effluent treatments. The more concentration and frequency of distillery effluent treatment of soil may change its ion exchange capacity, $\mathrm{pH}$ due to higher accumulation of nutrients as well as toxicants, microbial activities and may make various nutrients like calcium, magnesium, sodium and potassium lesser available to the crop plants that might have ultimately resulted reduction in the growth performance of the crop $T$. foenum-graecum as also observed earlier by Kumar et al. (2010) for the agronomical performance of the $T$. foenum-graecum plant which was gradually increased at low effluent concentration of paper mill i.e., from 5 to $25 \%$ while it decreased at higher effluent concentrations i.e., from 50 to $100 \%$ as compared to control. The maximum seed germination of $T$. foenum-graecum was recorded at $25 \%$. At vegetative growth, flowering, fruiting stage and maturity stage of $T$. foenum-graecum, the maximum values of shoot length, root length, number of leaves, chlorophyll content, biomass number of flowers and number of pods/plant, number of secondary roots, root nodules, pod length and crop yield/plant were recorded at $25 \%$ effluent concentration of paper mill effluent.

\section{Conclusions}

The present study concluded that the DE of the Shamli distillery and Chemical works, Shamli Muzaffarnagar increased the moisture content; WHC, bulk density and decreased it $\mathrm{pH}$. EC, $\mathrm{Cl}^{-}, \mathrm{TOC}, \mathrm{HCO}_{3}^{-}, \mathrm{CO}_{3}^{-}$ ${ }^{2}, \mathrm{Na}^{+}, \mathrm{K}^{+}, \mathrm{Ca}^{2+}, \mathrm{Mg}^{2+}, \mathrm{Fe}^{2+}, \mathrm{TKN}, \mathrm{NO}_{3}^{2-}$, $\mathrm{PO}_{4}{ }^{3-}$ and $\mathrm{SO}_{4}{ }^{2-}$ of the soil. Thus, irrigation improved the soil nutrient status. All effluent concentrations were better than the control in nutrient accumulation. The agronomical performance of the $T$. foenumgraecum plant was recorded in gradually increasing order at low effluent concentration i.e., from 5 to $50 \%$ while in decreasing order at higher effluent concentration i.e., from 75 to $100 \%$ as compared to control at various stages. Stimulation was observed in seed emergence period and shoot length, root length and biomass of the crop with the increase in effluent concentrations in emergence and early seedling (0-30 days) growth period.

The maximum growth performance of the plant was observed at $50 \%$ effluent concentration. It may be due to the low nutrients accumulation in the soil at this $50 \%$ effluent concentration that might have stimulated the growth performance. However, more irrigation increased the accumulation of nutrients at higher effluent concentration i.e., 75 and $100 \%$, thus inhibited the overall performance of the crop plants. Thus, there are certain growths stimulating as well as inhibiting substances present in the DE which are responsible for this growth pattern. The effluent has potentiality for its use as agro-based biofertigant in the form of plant nutrients 
needed by $T$. foenum-graecum crop plant. Therefore, it can be used as agro-based biofertigant after its appropriate dilution for irrigation purposes for the maximum yield of this crop and to maintain soil health.

\section{Acknowledgements}

The University Grants Commission, New Delhi, India is acknowledged for providing the financial support in the form of UGC research fellowship (F.7-70/2007-2009 BSR) to Dr. V. Kumar.

\section{References}

AIDA 2004. All India Distillery Association and Sugar Technology Association of India. Annual Report, New Delhi, retrieved on $17^{\text {th }}$ April, 2008 from (http://www.aidaindia.org/).

APHA 2005. In Standard methods for the examination of Water and Wastewater. 21st edition, American Public Health Association, Washington, DC.

Bharagava, R.N., R. Chandra and V. Rai 2008. Phytoextraction of trace elements and physiological changes in Indian mustard plants (Brassica nigra L.) grown in post methanated distillery effluent (PMDE) irrigated soil. Bioresource Technol. 99(17): 8316-8324.

BIS 1991. Bureau of Indian Standards. In Indian standards for drinking water. Specification (BIS 10500:1991) retrieved on $20^{\text {th }}$ April, 2007 from (http:// www.bis.org.in/).

Bouyoucos, G.J. 1962. Hydrometer method improved for making particle size analysis of soils. Agron. J. 54: 464.

Buurman, P.B., L. Van and E.J. Velthrost 1996. Manual of soil and water analysis. Backhuys Publisher, Leiden, The Netherland.

Carter, M.R. 1993. In: Soil sampling and method of analysis. Lewis Publishers, Boca Raton, FL.

Chandrasekhar, N., A. Subramani and S. Saravana 1998. Effect of sugar mill effluent on germination and early seeding growth of black gram [Vigna mungo (L) Hepper var. ADT-3). Indust. Poll. Cont. 14: 73-78.
Chapagain, N. 1991. Physiological impact of Dhobikhola water pollution on Persicaria perfoliata leaves and germination of some vegetables seeds. In Conf., CD Int. Workshop, Irrigation technologies and method: Research, development and testing. Montpellier, France.

Charman, P.E.V. and B.W. Murphy 1991. Soils. Their properties and management. In A Soil Conservation Handbook for New South Wales. Sydney University Press, Sydney.

Denison, R.F. and R. Russotti 1997. Field estimates of green leaf area index using laser-induced chlorophyll fluorescence. Field Crops Res. 52: 143-150.

Hati, K.M., A.K. Biswas, K.K. Bandyopadhyay and A.K. Misra 2007. Soil properties and crop yields on a vertisol in India with application of distillery effluent. Soil and Tillage Research 92(1-2): 60-68.

Hussain, I., R. Liqa, A. Munir, M.H. Fuard and W. van der Hoek 2001. Framework for analyzing socioeconomic, health and environmental impacts of wastewater use in agriculture. IWMI working paper 26. International Water Management Institute, Colombo, Sri Lanka.

Kannan, A. and R.K. Upreti 2008. Influence of distillery effluent on germination and growth of mung bean (Vigna radiata, L.R. Wilczek) seeds. J. Hazardous Materials 53(1-2): 609615 .

Karunyal, S., G. Renuga and K. Paliwal 1994. Effect of tannery effluent on seed germination, leaf area, biomass and mineral content of some plants. Bioresource Technol. 47: 215-218.

Kaul, S.N., T. Nandy and R.K. Trivedy 1995. In Pollution control in distilleries. Enviro. Media, Karad, India. pp. 268.

Kaushik, A., R. Nisha, K. Jagjeeta and C.P. Kaushik 2005. Impact of long and short term irrigation of a sodic soil with distillery effluent in combination with bioamendments. Bioresource Technol. 96(17): 1860-1866.

Kumar, V., A.K. Chopra, C. Pathak and S. Pathak 2010. Agro-potentiality of paper mill effluent on the characteristics of Trigonella foenumgraecum L. (Fenugreek). New York Sci. J. 3(5): 68-77. 
Milner, C. and R.E. Hughes 1968. Methods for the measurement of primary production of grassland. IBP Hand Book No.6 Blackwell Sci. Pub. Oxford, England.

Orhue, E.R., Osaigbovo, U. Agbonsalo, Vwioko and E. Dennis 2005. Growth of maize (Zea mays L.) and changes in some chemical properties of an ultisol amended with brewery effluent. African J. Biotechnol. 4(9): 973-978.

Osaigbovo, U. Agbonsalo, E.R. Orhue 2006. Influence of pharmaceutical effluent on some soil chemical properties and early growth of maize (Zea mays L). African J. Biotechnol. 5(12): 1612-1617.

Pandey, S.K., P. Tyagi and A.K. Gupta 2007. Physico-chemical analysis and effect of distillery effluent on seed germination of wheat (Triticum aestivum), pea (Pisum sativum) and lady's finger (Abelmoschus esculentus). Journal of Agricultural and Biological Science, 2 (6): 35-40.

Patterson, S.J., D.S. Chanasyk, E. Mapfumo and M.A. Naeth 2008. Effects of diluted Kraft pulp mill effluent on hybrid poplar and soil chemical properties. Irrig. Sci. 26: 547-560.
Porra, R.J. 2002. The chequered history of the development and use of simultaneous equations for the accurate determination of chlorophylls $a$ and $b$. Photosynthesis Research 73: 149-156.

Ramana, S., A.K. Biswas, S. Kundu, J.K. Saha and R.B.R. Yadava 2002. Effect of distillery effluent on seed germination in some vegetable crops. Bioresource Technol. 82(3): 273-275.

Saravanamoorthy, M.D. and B.D. Ranjitha Kumari 2007. Effect of textile waste water on morpho-physiology and yield on two varieties of peanut (Arachis hypogaea L.). $J$ Agricultural Technol. 3(2): 335-343.

Shainberg, I. and J.D. Oster 1978. Quality of irrigation water. Pergamon Press, London.

Sinclair, T.R. 1998. Historical changes in harvest index and crop nitrogen accumulation. Crop Science 38: 638-643.

Thompson, G., J. Swain, M. Kay and C.F. Forster 2001. The treatment of pulp and paper-mill effluent: A review. Bioresource Technol. 77(3): 275-286. 